\title{
Kvalitative analysemetoder i sundhedsforskning
}

\section{Frederik Alkier Gildberg \& Lise Hounsgaard (red.)}

Lærke Bing Røikjer

Antropologi, Aarhus Universitet

laerke_bing@hotmail.com

271 sider. Klim. 2018.

At analysere sine data er en central proces af ethvert forskningsprojekt. Analyse som begreb vil være del af langt de fleste studieordninger, ligesom det vil være forventet at indgå i studier på højere niveau. Begrebet, der kommer fra græsk, betyder at opløse, og peger altså på en proces, der deler en stor (ofte uoverskuelig) mængde data ind i mindre emner/pointer. Men hvordan gøres dette i praksis? Det er netop, hvad denne antologi prøver at give en række svar på. Den forsøger at indføre læseren i udvalgte kvalitative analysemetoder relevant for humanistisk sundhedsforskning.

Bogen er opbygget af kapitler skrevet af forskellige forfattere, hver med deres egen faglighed indenfor eksempelvis sundhedspleje, filosofi, antropologi eller læringsprocesser. Det, der binder alle forfatterne sammen, er deres erfaring med at arbejde med lige netop deres fag inden for et sundhedsvidenskabeligt felt. Forfatterne præsenterer sådan hver deres analysemetode, der kendetegner lige netop deres fag, men som kan bruges bredere indenfor kvalitativ sundhedsforskning - eller hvis du spørger mig, inden for kvalitativ forskning generelt. Antologien kan på denne måde fungere både som en bog, der læses fra ende til anden for 
at give læseren en grundig forståelse for analysemetodernes pluralitet eller som et opslagsværk, der kan belyse konkrete teknikker. Antologien er struktureret således, at kapitlerne bevæger sig fra at være introducerende omkring, hvordan man vælger analysemetode og håndterer sin data, til at gennemgå specifikke analysemetoder opdelt efter tradition - først med fokus på pragmatiske metoder, da på fænomenologiske og hermeneutiske og siden med blik på metoder inden for kritisk teori.

Bogen er et bud på en indledende litteratur rettet mod studerende på bacheloreller kandidatniveau, der skal give sig i kast med kvalitative analysemetoder. Forfatterne synes ikke at antage, at læseren har nogen form for forudgående viden på området, hvorfor kapitlerne forsøger at give en lettilgængelig og forståelig introduktion til hver metode gennem en indføring i den grundlæggende teori bag samt med eksemplificering af dens brug fra forfatternes egen forskning. Dette styrkes blandt andet gennem brugen af metaforer, ordforklaringer, figurer og tekstbokse. Antologien minder derfor på mange måder om en klassisk lærebog. Desuden opsummeres hver metode med en vurdering af dens sværhedsgrad for studerende på forskelligt niveau samt ofte en henvisning til, hvor der kan hentes yderligere viden om emnet. Selvom antologien er rettet mod fagligheder fra forskellige traditioner, skinner redaktørernes sundhedsfaglige baggrund igennem; både når det kommer til valg af forfattere, samt i de eksempler, der drages brug af i introduktionen. Således synes bogen måske mere oplagt for studerende indenfor dette felt, der skal prøve kræfter med humanistisk analyse.

Kvalitative analysemetoder $i$ sundhedsforskning er ikke det første værk, der behandler kvalitative analytiske strategier. Der findes mange andre bøger og artikler på både dansk og engelsk, der giver deres forslag til, hvordan analysen kan udføres - eksempelvis James Spradley's Participant Observation fra 2000 eller Helle Bundgaard og Hanne Overgaard Mogensens artikel i Antropologiske projekter: En grundbog fra 2018. Til forskel fra mange af disse værker, synes nærværende antologi at beskæftige sig med selv de mest grundlæggende antagelser i relation til kvalitativ analyse - måske netop fordi den i høj grad er rettet mod studerende med sundhedsfaglig baggrund, der måske ikke før har arbejdet kvalitativt. Antologien sætter derfor ord på selv de ting, der for den mere øvede analytiker vil virke næsten for åbenlyse, idet der huskes på, at det måske ikke er åbenlyst for nybegynderen.

Grundet antologiens opbygning, hvor hvert kapitel har sit eget tema og sin egen forfatter, står hver metode meget alene. Selvom bogen derfor ikke tilbyder læseren et helstøbt billede af analyseprocessen, synes den alligevel at opnå sit mål om at indføre læseren i basale teknikker og give en grundlæggende idé om nogle af de 
metoder, der findes. Hvor bogen mangler dybde, har den til gengæld bredde - og dette må efter min mening klart siges at være dens styrke taget dens publikum i betragtning. Dog vil jeg mene, at bogen savner et mere fokuseret blik på, hvorfor disse metoder er interessante for netop sundhedsforskning - særligt taget titlen i betragtning. Selvom alle forfatterne selv har lavet forskning inden for dette felt og derfor giver empiriske eksempler eller fremstiller cases, de selv har arbejdet med inden for det sundhedsvidenskabelige, synes disse at være udskiftelige med kvalitativ empiri fra enhver anden kontekst. Metoderne, der også bruges i bredere kvalitativ forskning, synes altså ikke mere relevante for forskning om sygdom og sundhed end andre felter. Man kan måske derfor også stille spørgsmålstegn til det store antal af forfatterne, der befinder sig indenfor et felt, der nok har god erfaring med sundhedsfaglig forskning, men måske ikke har speciale i kvalitativ analyse. Omendskønt, vil jeg dog anbefale bogen til enhver uden videre erfaring, som ønsker en grundig og velskrevet indførsel i den grundlæggende del af analyseprocessen. 